\title{
EPHEMEROPTERA, PLECOPTERA AND TRICHOPTERA ASSEMBLAGES FROM RIFFLES IN MOUNTAIN STREAMS OF CENTRAL BRAZIL: ENVIRONMENTAL FACTORS INFLUENCING THE DISTRIBUTION AND ABUNDANCE OF IMMATURES
}

\author{
BISPO, P. C. ${ }^{1}$, OLIVEIRA, L. G. ${ }^{2}$, BINI, L. M. ${ }^{2}$ and SOUSA, K. G. ${ }^{2}$ \\ ${ }^{1}$ Departamento de Ciências Biológicas, FCLA, UNESP, Av. Dom Antônio, 2100, \\ C. P. 65, CEP 19806-900, Assis, São Paulo, Brazil \\ ${ }^{2}$ Departamento de Biologia Geral, ICB, UFG, Campus Samambaia, C. P. 131, CEP 74001-970, Goiânia, Goiás, Brazil \\ Correspondence to: Pitágoras C. Bispo, Departamento de Ciências Biológicas, FCLA, UNESP, Av. Dom Antônio 2100 , \\ C. P. 65, CEP 19806-900, Assis, São Paulo, Brazil, e-mail: pitagoras@ assis.unesp.br \\ Received May 10, 2004 - Accepted July 13, 2004 - Distributed May 31, 2006
}

(With 4 figures)

\begin{abstract}
The influence of environmental factors on the distribution of Ephemeroptera, Plecoptera and Trichoptera (EPT) immatures was investigated in streams of the Brazilian Center-West (Serra do Pireneus, Pirenópolis, State of Goiás). The insects were sampled by lifting the stones in front of a sieve $(0.5 \mathrm{~mm}$ mesh) and then removing the insects from both the stone and the sieve. Sampling was carried out for $1 \mathrm{~h}$ at 5 collection sites over a period of 14 months. Air and water temperature $\left({ }^{\circ} \mathrm{C}\right)$, water velocity $(\mathrm{m} / \mathrm{s})$, discharge $\left(\mathrm{m}^{3} / \mathrm{s}\right)$, electric conductivity $(\mu \mathrm{S} / \mathrm{cm}), \mathrm{pH}$, and rainfall $(\mathrm{mm})$ were also recorded. In general, we may state that altitude, hydrologic classification (order) and vegetation cover were the most important factors explaining the distribution of Ephemeroptera, Plecoptera and Trichoptera immatures. The influence of the rainfall on the temporal variation of the abundance of insects was stronger in stream segments of medium order $\left(3^{\text {rd }}, 4^{\text {th }}\right.$ order) compared to smaller streams (first order).
\end{abstract}

Keywords: Ephemeroptera, Plecoptera, Trichoptera, lotic environments, larval distribution.

\section{RESUMO}

\section{Comunidades de Ephemeroptera, Plecoptera e Trichoptera em riachos de montanha do Brasil Central: fatores ambientais influenciando a distribuição e abundância}

A influência de fatores ambientais sobre a distribuição de imaturos de Ephemeroptera, Plecoptera e Trichoptera (EPT) foi investigada em riachos do Centro Oeste Brasileiro (Serra do Pireneus, Pirenópolis, Estado de Goiás). Os insetos foram amostrados lavando pedras em frente a um rede $(0,5 \mathrm{~mm}$ de malhas) e removendo os insetos tanto das pedras quanto das redes. A amostragem foi feita durante $1 \mathrm{~h}$ em cinco pontos de coleta em um período de 14 meses. Temperaturas do ar e da água $\left({ }^{\circ} \mathrm{C}\right)$, velocidade da água $(\mathrm{m} / \mathrm{s})$, vazão $\left(\mathrm{m}^{3} / \mathrm{s}\right)$, condutividade elétrica $(\mu \mathrm{S} / \mathrm{cm}), \mathrm{pH}$, e precipitação pluviométrica $(\mathrm{mm})$ também foram registradas. Em geral, podemos afirmar que a altitude, a classificação hidrológica (ordem) e a cobertura vegetal foram os fatores mais importantes na distribuição de imaturos de Ephemeroptera, Plecoptera e Trichoptera. A influência da precipitação pluviométrica sobre a variação temporal da abundância foi maior em trechos de ordem média ( $3^{\mathrm{a}}, 4^{\mathrm{a}}$ ordem) quando comparado aos menores riachos (primeira ordem).

Palavras-chave: Ephemeroptera, Plecoptera, Trichoptera, ambientes lóticos, distribuição larval. 


\section{INTRODUCTION}

Aquatic insects are important elements in the ecological dynamics of lotic environments (Hynes, 1970) playing an important role in the cycle of materials and in trophic transfers (Cummins, 1974; Vannote et al., 1980; Cummins et al., 1989). The communities of aquatic insects are affected by several factors related to water quality, stream morphology, food availability and quality (Vannote et al., 1980; Zamora-Muñoz et al., 1993; Richards et al., 1993; Usseglio-Polatera \& Tachet, 1994; Diniz-Filho et al., 1998). It is important to understand how these communities are structured and to identify the main environmental factors that determine their composition and abundance in lotic environments, mainly because this provides information for biomonitoring and recovery of these environments when they are degraded (Peterson \& Van Eeckhaute, 1992; Richards et al., 1993; Zamora-Muñoz \& Alba-Tercedor, 1996).

Basic aspects of the aquatic insect fauna are unknown in tropical regions despite important contributions made over the last few years (Dudgeon, 1990; 1996; 1997; Burton \& Sivaramakrishnan, 1993; Flecker \& Feifarek, 1994; Yule, 1995; Melo \& Froehlich, 2001). In tropical regions, rainfall varies considerably throughout the year (Flecker \& Feifarek, 1994). Therefore, rainfall seasonality is probably the main factor that controls the temporal distribution of aquatic insect communities in these regions (Boon et al., 1986; Flecker \& Feifarek, 1994).

Among aquatic insects, Ephemeroptera, Plecoptera and Trichoptera (EPT), comprise rich assemblages in low and medium order stony cobble streams. These organisms are sensitive to environmental perturbations and occur in clean and well oxygenated waters. Therefore, EPT assemblages are frequently considered to be good indicators of water quality (Rosenberg \& Resh, 1993).

In the present study we obtained data on EPT abundance and some environmental factors in Center-West Brazilian streams in order to determine the major environmental factors, among limnologic and physiographic, which might explain the distribution of the EPT fauna. The effects of rainfall on EPT abundance were also assessed.

\section{MATERIAL AND METHODS}

\section{Study area}

The study was conducted in the basin of the Almas river, Municipality of Pirenópolis, state of Goiás. The origins of the Almas river are in the Serra dos Pireneus (Pireneus mountain chain) and comprise various steep streams with stony or sandy bottoms and some pools with leaf debris. These tributaries flow along the western slope of the mountain chain and are part of the hydrographic network of the Amazon basin. The study was conducted along the Inferno stream in its first order segment, along the Almas river, both along its segment in the Pireneus chain and near Pirenópolis, inside the town, and along the Vagafogo stream, a $1^{\text {st }}$ order tributary of the Rio das Almas river downstream from the town (Fig. 1). According to Nimer (1989), this region has a semi-humid tropical climate, with a rainy season in summer (marked rainfall between December and February) and a dry season in winter (May to September).

\section{Stations, sampling and taxonomic identifications}

Five stations (Fig. 1 and Table 1) were established and sampled monthly over a period of 14 months (June, 1993 to July, 1994). The classification proposed by Strahler (1957) was used to determine the stream order. Vegetation cover was scored on an ordinal scale from 0 to 3 as follows: 0 , none; 1 , sparse; 2 , medium; and 3 , a high percentage of vegetation cover (Bispo \& Oliveira, 1998).

Invertebrates were collected in riffles with cobble substrates. Insects were sampled by lifting the stones in front of a sieve $(0.5 \mathrm{~mm}$ mesh $)$ and then removing the insects from both the substrate and the sieve. Sampling was done for $1 \mathrm{~h}$. The material was then labeled and preserved in $80 \%$ alcohol. In the laboratory, the EPT immatures were sorted and identified to genus level, the level possible for EPT immatures in the region, based on reports by Dominguez et al. (1992) for Ephemeroptera, Benedetto (1974) and Froehlich (1984) for Plecoptera, and Angrisano (1995) and Wiggins (1996) for Trichoptera.

\section{Abiotic factors}

At each sampling station, the following abiotic factors were recorded: air and water 


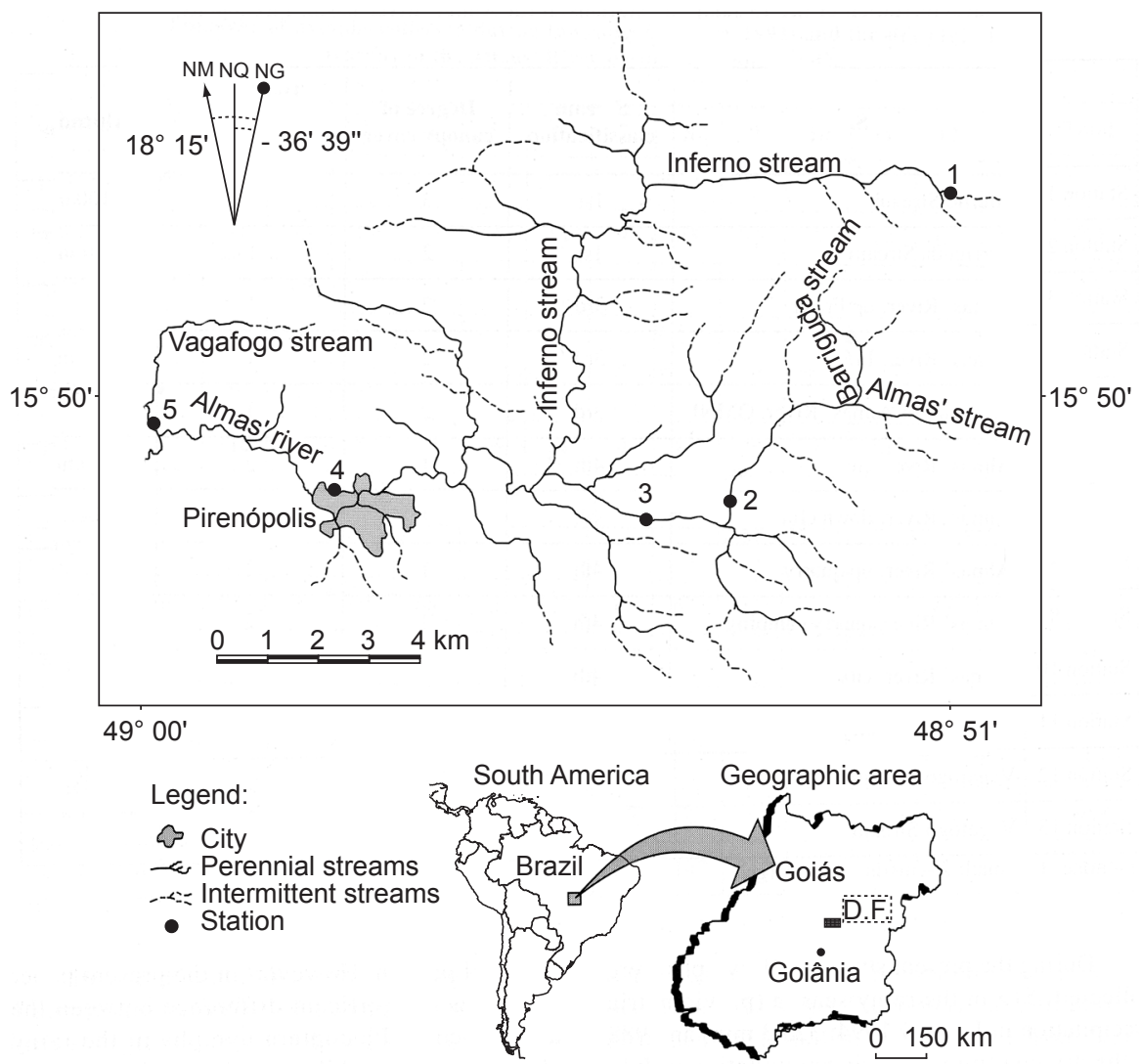

Fig. 1 - Map of the Almas' river basin, Pirenópolis Municipality, GO, showing the sampling stations.

TABLE 1

Environmental characterization of the 5 stations established along the streams of Serra dos Pireneus (Pireneus Range), Pirenópolis, state of Goiás.

\begin{tabular}{|l|c|c|c|c|c|}
\hline \multicolumn{1}{|c|}{ Stations } & $\mathbf{1}$ & $\mathbf{2}$ & $\mathbf{3}$ & $\mathbf{4}$ & $\mathbf{5}$ \\
\hline Altitude $(\mathrm{m})$ & 1100 & 780 & 750 & 730 & 710 \\
\hline Order & $1^{\text {st }}$ & $3^{\text {rd }}$ & $4^{\text {rd }}$ & $4^{\text {rd }}$ & $1^{\text {st }}$ \\
\hline $\begin{array}{l}\text { Degree of Vegetation } \\
\text { Cover }\end{array}$ & 3 & 2 & 1 & 0 & 3 \\
\hline Water temperature $\left({ }^{\circ} \mathrm{C}\right)$ & $18.607 \pm 1.212$ & $19.071 \pm 1.785$ & $20.492 \pm 2.102$ & $20.417 \pm 2.601$ & $20.643 \pm 1.994$ \\
\hline Air temperature $\left({ }^{\circ} \mathrm{C}\right)$ & $20.607 \pm 1.923$ & $21.250 \pm 3.756$ & $22.607 \pm 3.212$ & $22.000 \pm 4.385$ & $22.071 \pm 2.630$ \\
\hline Water velocity $(\mathrm{m} / \mathrm{s})$ & $0.295 \pm 0.084$ & $0.479 \pm 0.140$ & $0.659 \pm 0.248$ & $0.830 \pm 0.250$ & $0.376 \pm 0.134$ \\
\hline Discharge $\left(\mathrm{m}^{3} / \mathrm{s}\right)$ & $0.043 \pm 0.023$ & $0.647 \pm 0.382$ & $0.786 \pm 0.585$ & $3.086 \pm 2.387$ & $0.264 \pm 0.176$ \\
\hline $\mathrm{pH}$ & $7.409 \pm 0.266$ & $8.309 \pm 0.176$ & $8.418 \pm 0.232$ & $8.236 \pm 0.211$ & $7.545 \pm 0.211$ \\
\hline $\begin{array}{l}\text { Electrical Conductivity } \\
(\mu \mathrm{S} / \mathrm{cm})\end{array}$ & $8.636 \pm 5.045$ & $21.364 \pm 5.045$ & $29.454 \pm 7.091$ & $22.274 \pm 4.671$ & $16.818 \pm 4.045$ \\
\hline
\end{tabular}

temperature $\left({ }^{\circ} \mathrm{C}\right.$, with an alcohol thermometer), water velocity $(\mathrm{m} / \mathrm{s}$, by the floater method, Lind, 1979), flow ( $\mathrm{m}^{3} / \mathrm{s}$, method in Lind, 1979), electric conductivity $(\mu \mathrm{S} / \mathrm{cm}$, with a CORNING PS-17 conductivimeter), and hydrogenic potential $(\mathrm{pH}$, with a CORNING PS-15 pH-meter). The rainfall $(\mathrm{mm})$ in the Pirenópolis region was obtained from the $10^{\text {th }}$ Meteorologic District of the Ministry of 
Agriculture, Goiânia, state of Goiás. The total monthly rainfall was used as an index of temporal perturbation as a higher intensity and frequency of perturbations is expected in the months of heavier rainfall. According to Flecker \& Feifarek (1994), this is a crude index of the intensity and frequency of perturbation which, however, explained an important part of temporal variation in macroinvertebrate abundance in two Andean streams in Venezuela. The variations in flow may better represent these perturbations, but no daily data are available for this factor concerning the streams in the Pirenópolis region. The flow data presented here reflect only those observed on the sampling days and do not characterize the monthly variation. The index of temporal perturbation was characterized on the basis of the rainfall recorded during the month preceding sampling, according to Flecker \& Faifarek (1994).

\section{Data analysis}

The relationship between environmental variables and EPT was quantified by Canonical Correspondence Analysis (CCA) (Ter Braak, 1986) using the PCORD software (McCune \& Mefford, 1995). Some environmental variables were not recorded in June, July and August, 1993, so the CCA was carried out to data from September, 1993 to July, 1994. For the analyses, the matrices of the biotic and environmental factors, except $\mathrm{pH}$ and rank-ordered variables, were $\log$ transformed, in the case of the abundance matrix $\log (x+1)$. Total rainfall values in the month preceding samplings were included in the abiotic matrix used in CCA (Flecker \& Feifarek, 1994; Oliveira et al., 1997).

\section{RESULTS}

Sampling EPT immatures from June, 1993 to July, 1994 resulted in a total of 6,196 specimens belonging to 40 genera and 18 families. A total of 2,221 Ephemeroptera specimens were collected, corresponding to 16 genera and 5 families. For Plecoptera, 934 specimens were collected, belonging to 5 genera and 2 families, and for Trichoptera, 3,031 specimens were collected, belonging to 11 families and 19 genera. The genera are listed in Table 2.

The total variance of the EPT immature assemblages determined by CCA was 2.0207 . The total variance or inertia indicates the total amount of variability that might potentially be explained. The first three correlations between the biotic data set and the abiotic data set were $0.940,0.892$ and 0.921 , respectively. The first three axes derived from CCA accounted for $29.5 \%$ of the variation of the EPT immature assemblage. Monte Carlo simulations demonstrated that the first three axes were significant (Table 3).

CCA demonstrated that variables such as $\mathrm{pH}$, electric conductivity and stream order were negatively correlated with the first axis, whereas altitude and vegetation cover were positively correlated with it. Rainfall measured in the month preceding sampling was positively correlated with the second axis (Table 3 ).

The following patterns can be described. Campylocia, Massartella, Kempnyia, Gripopteryx, Tupiperla, Barypenthus, Oxyethira, Nectopsyche, Phylloicus, Macrogynoplax, Macronema Farrodes, and Marilia reached their optima in low order streams in areas of dense vegetation cover (Fig. 2). The first eight taxa of these preferentially occurred in the stream of highest altitude. Lachlania, Baetis s.l., Camelobaetidius, Hermanella, Needhamnella, Dicaminus, Hydroptila, Protoptila, Atopsyche, Aff. Dactylophlebia, Grumichella, Thraulodes, Chimarra and Leptohyphes reached their optima in the third and fourth order stretches (Fig. 2). The second CCA axis was mainly correlated with rainfall. Thus, to evaluate the influence of this variable on total EPT abundance, a separate and more detailed analysis was carried out.

The region of the Pireneus Range had two well-defined seasons, a rainy one and a dry one, with rainfall peaking between December and March. The driest months were those from May to August (Fig. 3). Air temperature in the region ranged from 17.5 to $24.5{ }^{\circ} \mathrm{C}$. The highest air temperatures occurred between August and November and the lowest between May and July (Fig. 3).

The relationships between rainfall and EPT abundance were better matched by a third degree polynomial. A slight fall in abundance was observed at station 1 during the rainy season (Fig. 4a). A high variation in abundance was observed at stations 2 and 3, with the drier months presenting a larger number of individuals and the rainy months a smaller number, although these relations were not linear (Figs. 4b and 4c). At station 4, the lowest 
TABLE 2

List of EPT immatures sampled from June/1993 to July/1994 in streams of Serra dos Pireneus (Pireneus Range), Pirenópolis, state of Goiás.

\begin{tabular}{|c|c|c|c|c|c|c|c|}
\hline \multirow[t]{2}{*}{ EPHEMEROPTERA } & & \multicolumn{5}{|c|}{ Station } & \multirow[t]{2}{*}{$\mathbf{N}$} \\
\hline & & 1 & 2 & 3 & 4 & 5 & \\
\hline \multicolumn{8}{|l|}{ Baetidae } \\
\hline Baetis s.l. Leach 1815 & Baet & $\mathrm{X}$ & $\mathrm{X}$ & $\mathrm{X}$ & $\mathrm{X}$ & $\mathrm{X}$ & 662 \\
\hline Aff. Bernerius Waltz \& McCafferty 1987 & Bern & $\mathrm{X}$ & $\mathrm{X}$ & $\mathrm{X}$ & $\mathrm{X}$ & $\mathrm{X}$ & 83 \\
\hline Camelobaetidius Demoulin 1966 & Cam & & $\mathrm{X}$ & $\mathrm{X}$ & $\mathrm{X}$ & $\mathrm{X}$ & 130 \\
\hline \multicolumn{8}{|l|}{ Euthiplociidae } \\
\hline Campylocia Needham \& Murphy 1924 & Сатp & $\mathrm{X}$ & & & & & 28 \\
\hline \multicolumn{8}{|l|}{ Leptohyphidae } \\
\hline Leptohyphes Eaton 1882 & Lepty & $\mathrm{X}$ & $\mathrm{X}$ & $\mathrm{X}$ & $\mathrm{X}$ & $\mathrm{X}$ & 821 \\
\hline \multicolumn{8}{|l|}{ Leptophlebiidae } \\
\hline Aff. Dactylophlebia Pescador \& Peters 1980 & Dact & & $\mathrm{X}$ & & & & 2 \\
\hline Aff. Demoulinellus Pescador \& Peters 1982 & Dem & $\mathrm{X}$ & $\mathrm{X}$ & $\mathrm{X}$ & & & 6 \\
\hline Farrodes Peters 1971 & Farr & $\mathrm{X}$ & $\mathrm{X}$ & & $\mathrm{X}$ & $\mathrm{X}$ & 13 \\
\hline Hermanella Needham \& Murphy 1924 & Herm & & & & $\mathrm{X}$ & & 2 \\
\hline Hylister Dominguez \& Flowers 1989 & Hyl & $\mathrm{X}$ & $\mathrm{X}$ & $\mathrm{X}$ & & & 12 \\
\hline Massartella Lestage 1930 & Mas & $\mathrm{X}$ & & & & & 123 \\
\hline Needhanmella Dominguez \& Flowers 1989 & Need & $\mathrm{X}$ & $\mathrm{X}$ & $\mathrm{X}$ & $\mathrm{X}$ & $\mathrm{X}$ & 81 \\
\hline Aff. Nousia Navás 1918 & $\mathrm{Nou}$ & $\mathrm{X}$ & $\mathrm{X}$ & $\mathrm{X}$ & $\mathrm{X}$ & $\mathrm{X}$ & 118 \\
\hline Thraulodes Ulmer 1920 & Thra & $\mathrm{X}$ & $\mathrm{X}$ & $\mathrm{X}$ & $\mathrm{X}$ & $\mathrm{X}$ & 144 \\
\hline Traverella Edmunds 1948 & Trav & & & & & $\mathrm{X}$ & 3 \\
\hline \multicolumn{8}{|l|}{ Oligoneuriidae } \\
\hline Lachlania Hagen 1868 & Lachl & & & & $\mathrm{X}$ & & 3 \\
\hline \multicolumn{8}{|l|}{ PLECOPTERA } \\
\hline \multicolumn{8}{|l|}{ Gripopterygidae } \\
\hline Gripopteryx Pictet 1841 & Grip & $\mathrm{X}$ & & & & & 16 \\
\hline Tupiperla Froehlich 1969 & Tup & $\mathrm{X}$ & & & & & 13 \\
\hline \multicolumn{8}{|l|}{ Perlidae } \\
\hline Anacroneuria Klapálek 1909 & Anac & $\mathrm{X}$ & $\mathrm{X}$ & $\mathrm{X}$ & $\mathrm{X}$ & $\mathrm{X}$ & 858 \\
\hline Kempnyia Klapálek 1914 & Keтp & $\mathrm{X}$ & $\mathrm{X}$ & & & $\mathrm{X}$ & 30 \\
\hline Macrogynoplax Enderlein 1909 & Macr & $\mathrm{X}$ & & & & $\mathrm{X}$ & 17 \\
\hline \multicolumn{8}{|l|}{ TRICHOPTERA } \\
\hline \multicolumn{8}{|l|}{ Calamoceratidae } \\
\hline Phylloicus Müller 1880 & Phyl & $\mathrm{X}$ & $\mathrm{X}$ & $\mathrm{X}$ & & $\mathrm{X}$ & 135 \\
\hline \multicolumn{8}{|l|}{ Glossosomatidae } \\
\hline Protoptila Banks 1904 & Prot & $\mathrm{X}$ & $\mathrm{X}$ & $\mathrm{X}$ & $\mathrm{X}$ & $\mathrm{X}$ & 552 \\
\hline \multicolumn{8}{|l|}{ Hydrobiosidae } \\
\hline Atopsyche Banks 1905 & Ato & $\mathrm{X}$ & $\mathrm{X}$ & $\mathrm{X}$ & $\mathrm{X}$ & $\mathrm{X}$ & 144 \\
\hline \multicolumn{8}{|l|}{ Helicopsychidae } \\
\hline Helicopsyche Siebold 1856 & $\mathrm{Hel}$ & $\mathrm{X}$ & $\mathrm{X}$ & $\mathrm{X}$ & & $\mathrm{X}$ & 87 \\
\hline \multicolumn{8}{|l|}{ Hydropsychidae } \\
\hline Leptonema Guérin 1843 & Lep & $\mathrm{X}$ & $\mathrm{X}$ & $\mathrm{X}$ & $\mathrm{X}$ & $\mathrm{X}$ & 639 \\
\hline Macronema Pictet 1836 & $M a c$ & $\mathrm{X}$ & & $\mathrm{X}$ & & $\mathrm{X}$ & 27 \\
\hline Smicridea McLachlan 1871 & Smi & $\mathrm{X}$ & $\mathrm{X}$ & $\mathrm{X}$ & $\mathrm{X}$ & $\mathrm{X}$ & 498 \\
\hline \multicolumn{8}{|l|}{ Hydroptilidae } \\
\hline Hydroptila Dalman 1819 & Hyd & & & $\mathrm{X}$ & & $\mathrm{X}$ & 9 \\
\hline Dicaminus Müller 1879 & Dic & & $\mathrm{X}$ & & & & 4 \\
\hline Oxyethira Eaton 1873 & $O x y$ & $\mathrm{X}$ & $\mathrm{X}$ & & & $\mathrm{X}$ & 14 \\
\hline \multicolumn{8}{|l|}{ Leptoceridae } \\
\hline Atanatolica Mosely 1936 & Ata & $\mathrm{X}$ & $\mathrm{X}$ & $\mathrm{X}$ & & & 7 \\
\hline Grumichella Müller 1879 & Gru & & $\mathrm{X}$ & $\mathrm{X}$ & & $\mathrm{X}$ & 136 \\
\hline
\end{tabular}


TABLE 2

Continued...

\begin{tabular}{|c|c|c|c|c|c|c|c|}
\hline \multicolumn{2}{|l|}{ EPHEMEROPTERA } & \multicolumn{5}{|c|}{ Station } & \multirow{2}{*}{\begin{tabular}{|l}
$\mathbf{N}$ \\
54
\end{tabular}} \\
\hline Nectonsvche Miiller 1879 & Nho & 1 & $\begin{array}{ll}2 & \\
& X\end{array}$ & 3 & \begin{tabular}{|lll}
4 & \\
& $X$ \\
\end{tabular} & $\begin{array}{|ll|}5 & \\
& X \\
\end{array}$ & \\
\hline Oecetis McLachlan 1877 & Nec & $\begin{array}{l}\Lambda \\
X\end{array}$ & \begin{tabular}{|l}
$\Lambda$ \\
$X$
\end{tabular} & $\mathrm{X}$ & $\begin{array}{l}\Lambda \\
X\end{array}$ & $\begin{array}{l}\Lambda \\
X\end{array}$ & 84 \\
\hline \multicolumn{8}{|l|}{ Odontoceridae } \\
\hline Barypenthus Burmeister 1839 & Bar & $\mathrm{X}$ & $\mathrm{X}$ & & & & 108 \\
\hline Marilia Müller 1880 & Mar & $\mathrm{X}$ & $\mathrm{X}$ & & & $\mathrm{X}$ & 100 \\
\hline \multicolumn{8}{|l|}{ Philopotamidae } \\
\hline Chimarra Stephens 1829 & Chi & $\mathrm{X}$ & $\mathrm{X}$ & $\mathrm{X}$ & $\mathrm{X}$ & $\mathrm{X}$ & 409 \\
\hline \multicolumn{8}{|l|}{ Polycentropodidae } \\
\hline Polycentropus Curtis 1835 & Pol & & & & & $\mathrm{X}$ & 6 \\
\hline \multicolumn{8}{|l|}{ Xiphocentronidae } \\
\hline Xiphocentron Brauer 1870 & Xip & $X$ & & $X$ & $\mathrm{X}$ & & 20 \\
\hline Genus Number & 40 & 31 & 28 & 23 & 19 & 27 & \\
\hline Total of Ephemeroptera nymphs & & 268 & 516 & 821 & 239 & 387 & 2231 \\
\hline Total of Plecoptera nymphs & & 286 & 221 & 93 & 22 & 312 & 934 \\
\hline Total of Trichoptera larvae & & 425 & 901 & 843 & 435 & 427 & 3031 \\
\hline Total & & 979 & 1638 & 1757 & 696 & 1126 & 6196 \\
\hline
\end{tabular}

TABLE 3

Results of CCA for the EPT fauna collected from September /1993 to July/1994 from streams of Serra dos Pireneus (Pireneus Range), Pirenópolis, state of Goiás.

\begin{tabular}{|l|c|c|c|}
\hline Total variance (“inertia") in the taxa data & $\mathbf{2 . 0 2 0 7}$ & & Axis III \\
\hline & Axis I & Axis II & $0.120^{* *}$ \\
\hline Eigenvalue & $0.346^{* *}$ & $0.130^{* *}$ & 6.0 \\
\hline Variance in taxa data & & & 29.5 \\
\hline \% of variance explained & 17.1 & 6.4 & $0.921^{* *}$ \\
\hline Cumulative \% explained & 17.1 & 23.5 & \\
\hline Pearson correlation, Táxons-Envt ${ }^{\mathrm{a}}$ & $0.940^{* *}$ & $0.892^{* *}$ & \\
\hline & & & -0.239 \\
\hline "intra set correlations" & & & 0.203 \\
\hline Water temperature & -0.120 & -0.026 & 0.189 \\
\hline pH & $\mathbf{- 0 . 8 0 4}$ & -0.164 & -0.239 \\
\hline Electrical conductivity & $\mathbf{- 0 . 7 9 6}$ & -0.389 & 0.015 \\
\hline Rainfall & 0.067 & $\mathbf{0 . 5 5 6}$ & 0.417 \\
\hline Altitude & $\mathbf{0 . 8 9 4}$ & -0.229 & -0.078 \\
\hline Vegetation cover & $\mathbf{0 . 7 5 0}$ & 0.431 & -0.435 \\
\hline Order & $\mathbf{- 0 . 8 2 2}$ & & \\
\hline
\end{tabular}

${ }^{\text {a }}$ Correlation between sample scores for an axis derived from the taxa data and the sample scores that linear combinations of the environmental variables; and $* * \mathrm{p}<0.01$ (Monte Carlo, 1000 permutations).

abundance occurred during the extreme periods of the dry season and of the rainy season, whereas the largest number of individuals occurred at the beginning of the rainy season (Fig. 4d). At station 5, the lowest abundance was recorded during the rainy months, whereas high and low abundance occurred during the dry season (Fig. 4e).

\section{DISCUSSION}

\section{EPT fauna in relation to environmental factors}

The present study revealed the predominance of some taxa for first order streams in areas of dense vegetation cover and the predominance of others for third or fourth order stretches in areas with low 


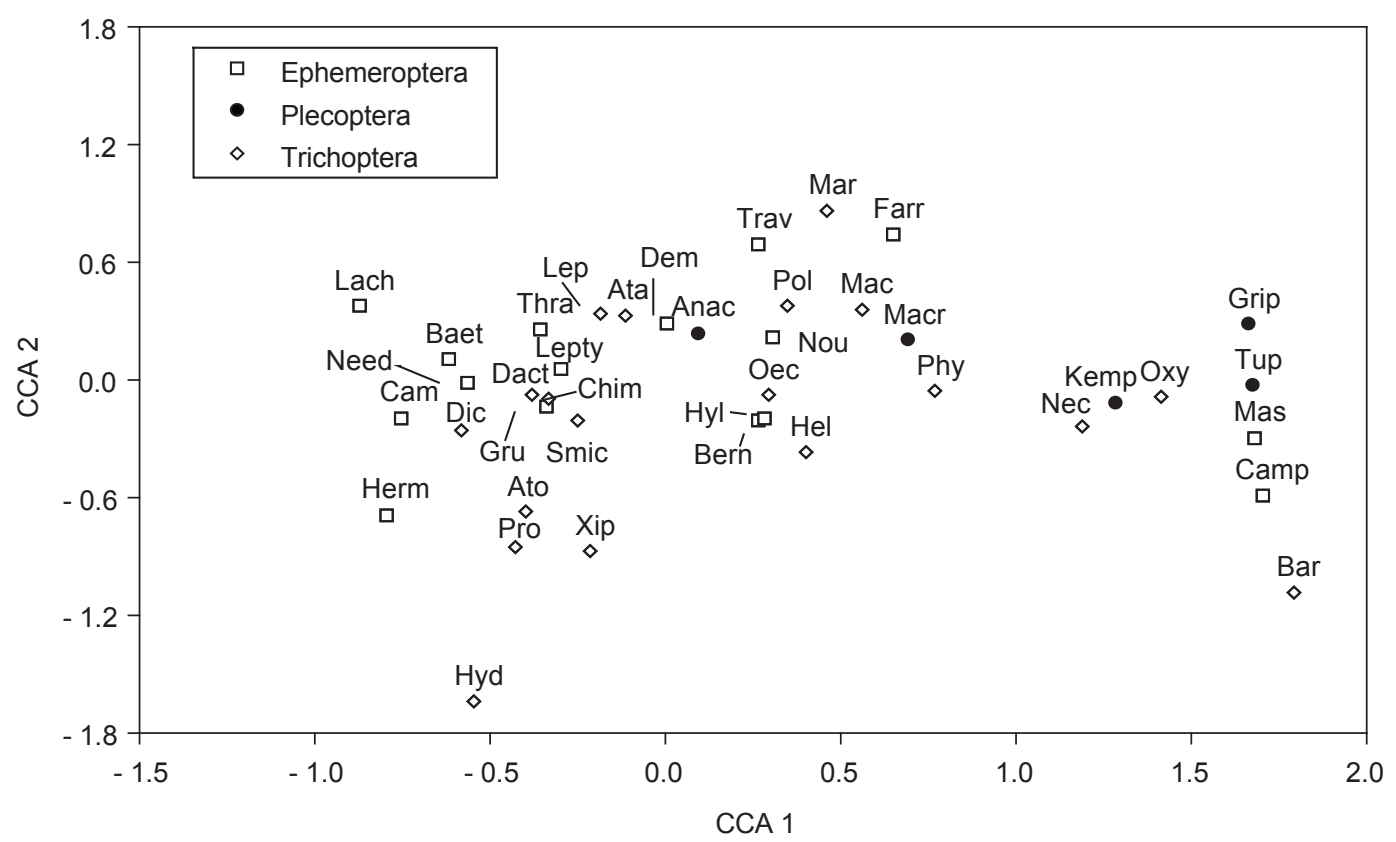

(a)

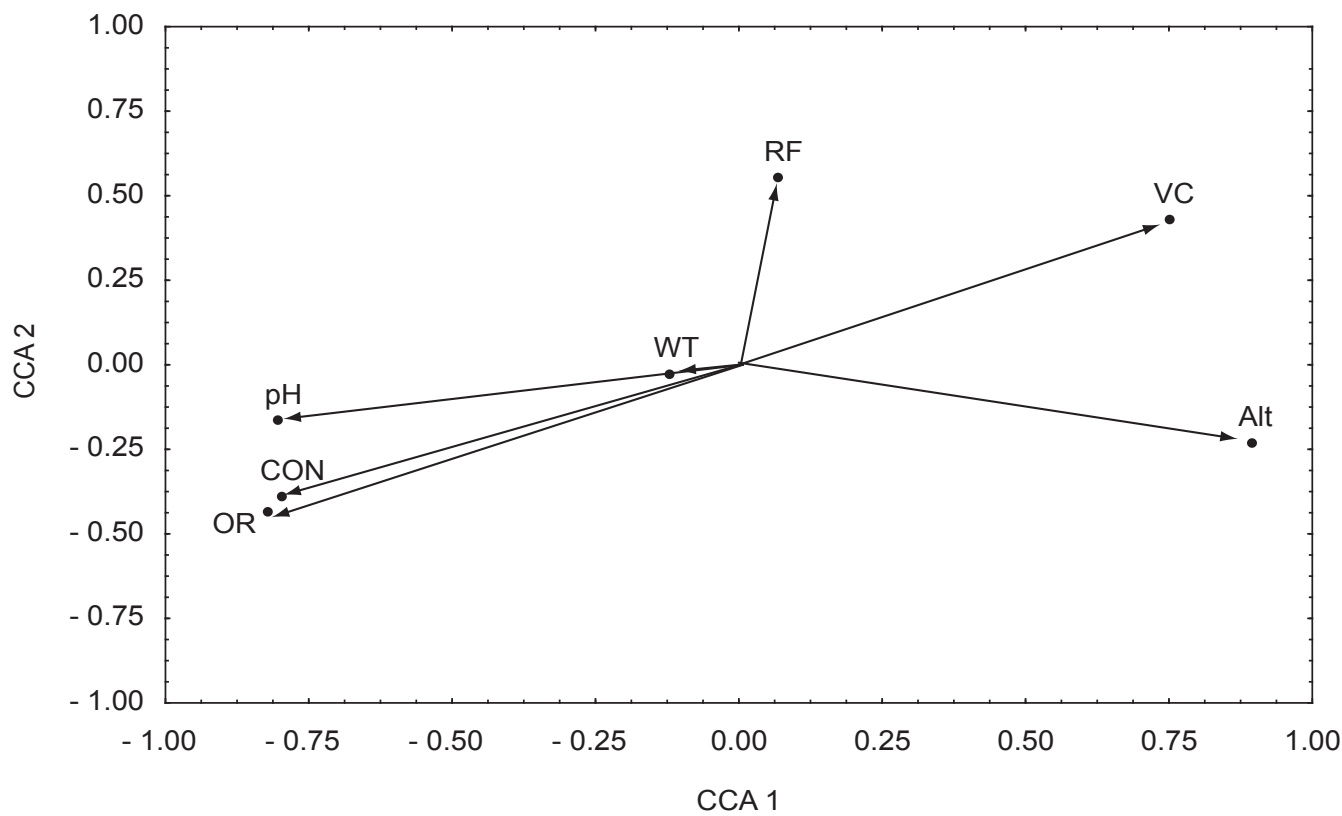

(b)

Fig. 2 - Scores of Canonical Correspondence Analysis for the EPT taxa (a) and for the environmental variables (b) recorded at five stations from September, 1993 to July, 1994 along streams of Serra dos Pireneus (Pireneus Range), Pirenópolis, State of Goiás. The names corresponding to the abbreviations of the taxa are listed in Table 2. Electrical conductivity (CON), Order (OR), Hydrogenionic Potential (pH), Vegetation cover (VC), Altitude (Alt), Water temperature (WT), and Rainfall (RF). 


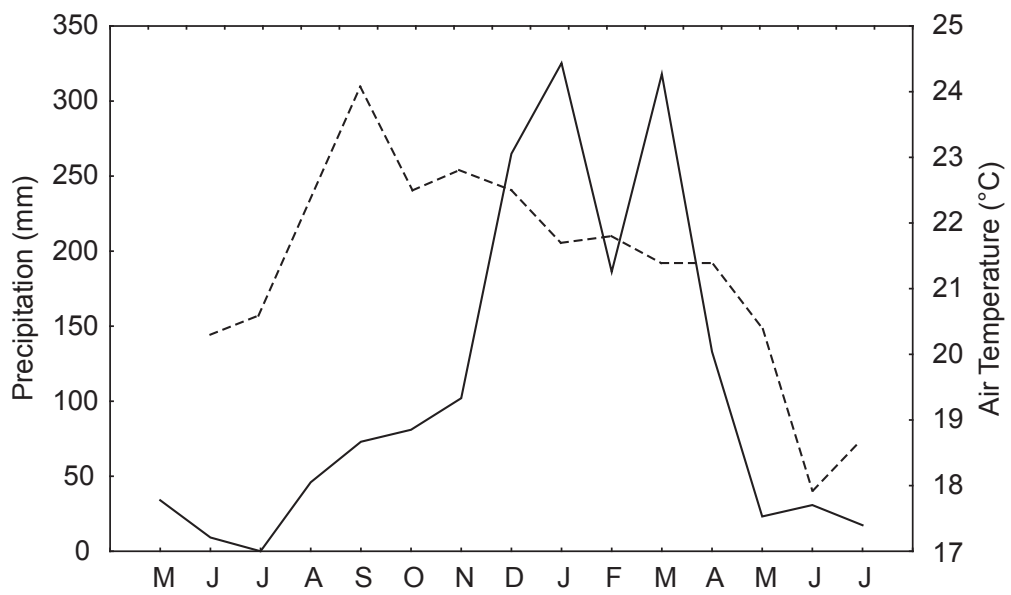

Fig. 3 - Variation of rainfall (May, 1993 to July, 1994), continuous line, and air temperature (June, 1993 to July, 1994), dashed line, for the Serra dos Pireneus region, Pirenópolis, state of Goiás.

vegetation cover. The highest $\mathrm{pH}$ and conductivity values were recorded in the higher order stretches. However, conductivity was low in the streams of the region, ranging from $<10$ to $40 \mu \mathrm{S} / \mathrm{cm}$, possibly indicating the good quality of water in these environments, in spite of station 4 receiving organic effluents. Electrical conductivity and $\mathrm{pH}$ influence the distribution of the fauna only at extreme values or when they are associated with organic pollution. Thus, our data suggest that the $\mathrm{pH}$ and conductivity values recorded during the study had no direct effect on the distribution of the EPT fauna. Hydrologic classification (order) was probably the most important factor, with the factors cited above being only redundant, i.e. presenting a variation correlated with the order of the streams. It is important to emphasize that underlining the increase in stream order are changes in the hydrologic conditions of a stream (Statzner \& Borchardt, 1994), in vegetation cover (Vannote et al., 1980), in food availability (Vannote et al., 1980), in the type and stability of the dominant substrate (Giller \& Malmqvist, 1998), and in the frequency and intensity of perturbation (Hildrew \& Towsend, 1987).

Altitude is an important factor when structuring different fauna compositions in lotic environments (Marchant et al., 1995; Carter et al., 1996). According to Macan (1962), this factor may influence aquatic organisms regarding their relationship to temperature. The increase in temperature may directly influence aquatic organisms or may lower oxygen solubility. Thus, some groups may limit their optima to zones of defined altitude (Illies, 1964; Dominguez \& Valdez, 1992). Despite the small difference in altitude among the streams studied, approximately $350 \mathrm{~m}$, the composition of some EPT groups in the Pireneus Range can be attributed to this factor. Plecoptera of the family Gripopterygidae are characteristic of regions of subtropical climate, although they also occur in mountainous tropical regions (Illies, 1964; Froehlich \& Oliveira, 1997). In the Serra do Pireneus they occurred at the station of highest altitude $(1,100 \mathrm{~m})$. Only one specimen was collected at station $5(710 \mathrm{~m})$. Additional samplings in the basin of the Almas river recorded the occurrence of specimens of Gripopterygidae also in a first order stream at an altitude of approximately $900 \mathrm{~m}$. Other taxa recorded only in the stream of highest altitudes were also recorded in other streams (not included in this study) with 700 to $750 \mathrm{~m}$ altitude in Almas river basin (PCB, personal observation), indicating that their distribution is not limited by this factor. Thus, only the distribution of Gripopterigydae (Gripopteryx and Tupiperla) was probably determined by environmental factors associated with higher altitudes.

In the Pireneus Range, stations 1 and 5 are streams in an area with dense vegetation cover and with various pools among the riffles. Moreover, a high accumulation of leaf debris occurs in these stations due to lower flow. Thus, many of the EPT showing predominance for these stations are organisms associated with accumulation of leaf debris such as the shredders Campylocia, Nectopsyche, 


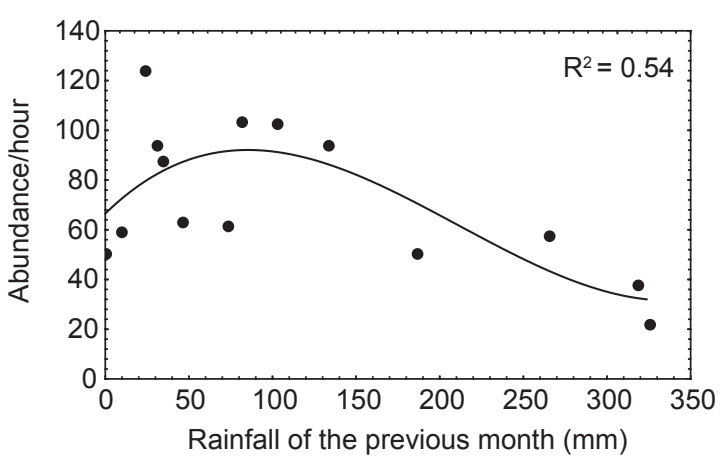

(a) Station 1

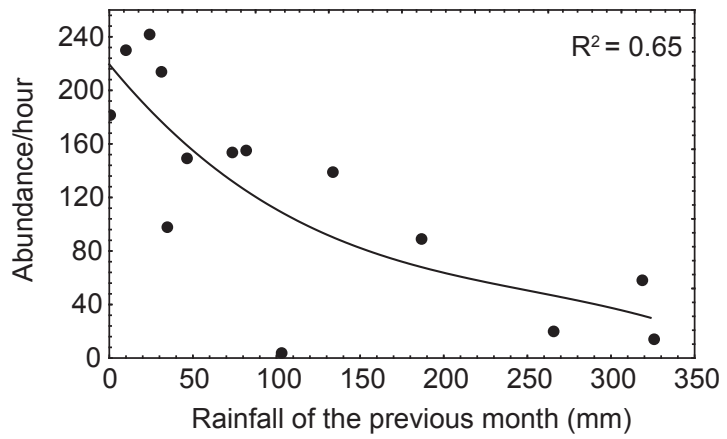

(c) Station 3

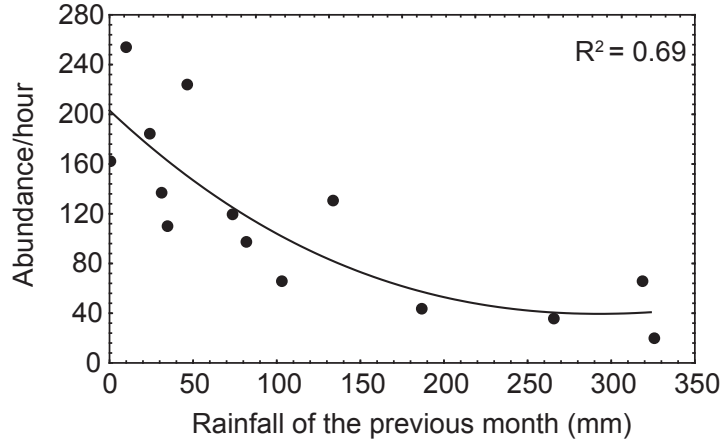

(b) Station 2

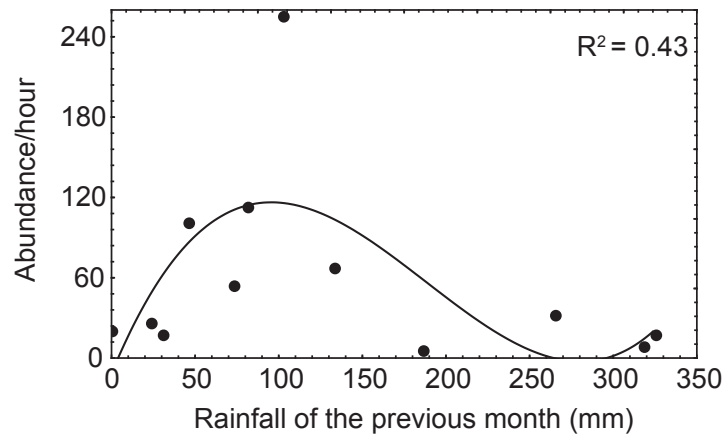

(d) Station 4

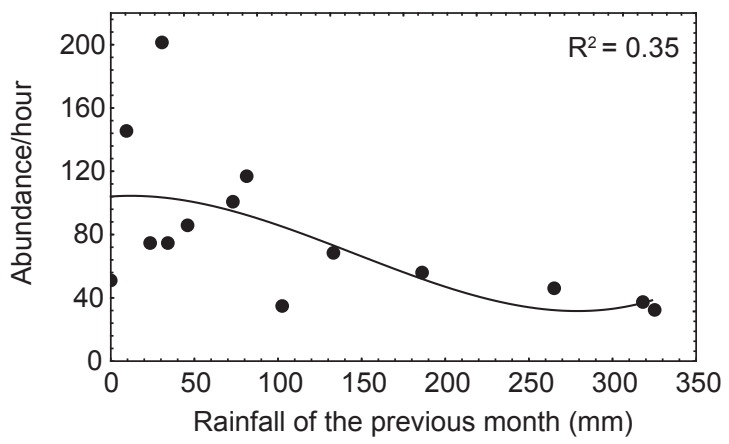

(e) Station 5

Fig. 4 - Third order polynomial relationship between rainfall (precipitation of the preceding month) and EPT abundance at 5 stations from June, 1993 to July, 1994, Serra dos Pireneus, Pirenópolis, state of Goiás.

Phylloicus and Marilia, the predators Barypenthus and Macrogynoplax, and the scraper Massartella. Other taxa such as Kempnyia (predator), Oxyethira (algal piercer), Macronema (collector) and Farrodes (scraper-collector) also showed predominance for first order streams. Insects such as Lachlania (collector), Baetis s.l. (collector), Camelobaetidius (collector), Hermanella (scraper-collector), Needhamnella (scraper-collector), Dicaminus (undefined), Hydroptila (scraper-collector), Protoptila (scraper), Atopsyche (predator), Aff. Dactylophlebia (scraper-collector), Grumichella (scraper-collector), Thraulodes (scraper-collector), Chimarra (collector) and Leptohyphes (scraper-collector) reached their optima at the stations along the Almas river (stations 2, 3 and 4), which are of higher order (third and fourth order) and have a lower vegetation cover. The vegetation cover was partial at stations 2 and 3 and absent at station 4. It is important to remember that much of the pre- 
dominance of these insects may be related to the use of resources, since scraper and shredder insects associated with leaf debris are expected to reach their optima at low order sites (first and second order) with dense vegetation cover, where there is more allochthonous material. On the other hand, in medium order stretches (third and fourth order), where there is a greater availability of periphyton and a larger amount of fine organic matter, scraper insects associated with the rocky substrate and collector insects are expected to reach their optima. These expectations were confirmed by the data obtained in the present study.

\section{Rainfall and abundance}

In the Cerrado region, the annual rainfall is typically highly seasonal. In lotic environments, in mountainous regions the increased water flow velocity during the rainy season may be considered one of the main factors determining the temporal variation in the abundance of benthic organisms (Boon et al., 1986; Flecker \& Feifarek, 1994; Rosser \& Pearson, 1995; Oliveira et al., 1997). During the rainy season, sudden increases in flow caused stream bed translocation, with the consequent removal of insects and a reduction in their local abundance (Flecker \& Feifarek, 1994). The increase in the density of organisms during periods of low flow may be related to the reduced availability of habitat area and the consequent increase in clustering of the individuals with the reduction of water level (Dudgeon, 1997; DinizFilho et al., 1998). According to Dudgeon (1997), even if there were no reduction in fauna due to the increased removal of organisms in the rainy season, the fact that the available area is increased would already be sufficient to reduce density. In this respect, Flecker \& Feifarek (1994) observed a negative relationship between rainfall and abundance of aquatic insects in two Andean streams in Venezuela. In the present study we observed that the rainfall explains an important part of the temporal variation in EPT abundance, especially at sites of greater flow (stations 2, 3 and 4). At stations 2 and 3, a decrease in abundance was observed during the rainy season, compatible with data reported by Flecker \& Feifarek (1994). For station 4 , with the entry of organic effluents, a peak of abundance was observed at the beginning of the rainy season, probably related to the possible improvement in water quality due to the reduction of organic matter concentration. Probably, the positive effects of pollutant dilution observed at the beginning of the rainy season are precluded in periods of higher precipitation rates $(>150 \mathrm{~mm})$. For stations 1 and 5, sites with a lower flow and denser vegetation cover, the rainfall had a lower effect on temporal variation in abundance.

The results demonstrate that first order streams were the most stable environments, with a smaller effect of precipitation on modification of the environment. In other words, leaf debris accumulation favors water infiltration into the soil, with the effect of precipitation on flow being only local. The larger streams receive various tributaries and therefore suffer the effect of water accumulation. In addition, in these streams the more reduced vegetation cover may reduce the infiltration of rainwater, favoring superficial drainage, increased flow and increased removal of organisms. Thus, the increase in precipitation and sum of the accumulated water in each tributary at a higher order (third and fourth order) streams causes a wide variation in water volume, submitting the organisms to a greater environmental variation. It should be pointed out that in heterogeneous environments, with a greater quantity of shelters, the increases in flow may be less drastic since, in these cases, many macroinvertebrates can protect themselves against the effect of the current (Scarsbrook \& Townsend, 1993; Towsend et al., 1997).

When perturbations occur in lotic environments they are followed by periods of colonization ranging from a few days to several years depending on the nature, intensity and persistence of this perturbation. The colonization by these organisms after perturbation can be quite rapid (Flecker \& Feifarek, 1994; McCabe \& Gotelli, 2000). Flecker \& Feifarek (1994) detected a positive correlation between the number of days since the last perturbation, the peak of precipitation, and the abundance of aquatic insects indicating that, the higher the number of days elapsed since the last perturbation, the longer the time available for restructuring the fauna. Thus, abundance may differ depending on when the sample was collected. This is a particular problem in field studies because the previous history of the site is rarely known.

In contrast to the data recorded in the present study, Melo \& Froehlich (2001) did not 
detect the influence of rainfall on the aquatic macroinvertebrate fauna in a region of the Atlantic forest in Southeastern Brazil, also not compatible with other studies carried out in the Cerrado region (Oliveira \& Froehlich, 1997; Oliveira et al., 1997; Bispo \& Oliveira, 1998) and in other tropical regions (Flecker \& Feifarek, 1994; Jacobsen \& Encalada, 1998). According to Melo \& Froehlich (2001), the fauna is probably adapted to predictable summer floods and its structure would be altered only by unusual catastrophic floods. These events probably also disturb the microhabitats that normally function as shelters for the fauna in the presence of smaller perturbations, a fact that reduces the source of individuals, which might have the potential to colonize unoccupied sites, causing the recovery of the fauna to be slower. However, it is important to emphasize that there is a marked difference in the annual rainfall between the Cerrado and Atlantic forest regions. In the Cerrado, the annual rainfall consists of better defined dry and rainy seasons than in the Atlantic forest where, depending on the region, the rains are less seasonal. In the Cerrado, since the rains are concentrated within a specific period of the year (November-April), perturbations are probably more intense and frequent during these periods. Allied to this, the denser vegetation cover in the Atlantic forest can reduce the frequency of sudden increases in flow since it provides for a better infiltration of rainwater. It should be pointed out that the rainfall seasonality can change in different years. Thus, we suggest that an important part of the temporal variation of aquatic insect abundances is determined by regional climatic seasonality (rainfall) and its interation with stream characteristics (discharge, vegetation cover, slope and substratum stability).

Acknowledgments - We are indebted to FUNAPE - UFG, for financial support during the field collections, to FAPESP for a fellowship granted to PCB, and to CNPq for fellowships granted to LGO and LMB. We also wish to thank Polyanna da C. Bispo for help with table typing. To Vera L. Crisci-Bispo, Cláudio G. Froehlich and Humberto Mendes for a critical reading of the manuscript.

\section{REFERENCES}

ANGRISANO, E. B., 1995, Insecta Trichoptera, pp. 1199-1224. In: Lopretto, E. C. \& Tell, G. (eds.), Ecosistemas de Aguas Continentales. Metodologias para su Estudio. $3^{\circ}$ vol., 897-1401p., Ediciones Sur, La Plata.
BENEDETTO, L., 1974, Clave para la determinacion de los plecopteros Sudamericanos. Stud. Neotrop. Fauna Environ., 9: $141-170$

BISPO, P. C. \& OLIVEIRA, L. G., 1998, Distribuição espacial de insetos aquáticos (Ephemeroptera, Plecoptera e Trichoptera) em córregos de cerrado do Parque Ecológico de Goiânia, Estado de Goiás, pp. 175-189. In: Nessimian, J. L. \& Carvalho, A. L. (eds.), Ecologia de Insetos Aquáticos, $5^{\circ}$ vol., XVII + 309p., Oecol. Bras., PPGE-UFRJ, Rio de Janeiro.

BOON, P. J., JUPP, B. P. \& LEE, D. G., 1986, The benthic ecology of rivers in the Blue Mountains (Jamaica) prior to construction of a water regulation scheme. Arch. Hydrobiol./ Suppl., 74: 315-355.

BURTON, T. M. \& SIVARAMAKRISHMA K. G., 1993, Composition of the insect community in the streams of the Silent Valley National Park in Southern India. Trop. Ecol., 34: 1-16.

CARTER, J. L., FEND, S. V. \& KENELLY, S. S., 1996, The relationships among three habitat scales and stream benthic invertebrate community structure. Freshw. Biol., 35: 109-124.

CUMMINS, K. W., 1974, Structure and function of stream ecosystems. BioScience, 24: 631-644.

CUMMINS, K. W., WILZBACH, M. A., GATES, D. M., PERRY, J. B. \&. TALIAFERRO, W. B., 1989, Shedders and riparian vegetation: leaf litter that falls into streams influences communities of stream invertebrates. BioScience, 39: 24-30.

DINIZ-FILHO, J. A. F., OLIVEIRA, L. G. \& SILVA, M. M., 1998, Explaining the beta diversity of aquatic insects in "cerrado" streams from Central Brazil using multiple Mantel Test. Revta Brás. Biol., 58(2): 223-231.

DOMINGUEZ, E. \& VALDEZ, J. M. B., 1992, Altitudinal replacement of Ephemeroptera in a subtropical river. Hydrobiologia, 246: 83-88.

DOMINGUEZ, E., HUBBARD, M. D. \& PETERS, W. L., 1992, Clave para ninfas y adultos de las familias y generos de Ephemeroptera (Insecta) sudamericanos. Biologia Acuática 16, NLP-CONICET, La Plata, $32 p+8$ plates.

DUDGEON, D., 1990, Benthic community structure and the effects of rotenone piscicide on invertebrte drift and standing stocks in two Papua New Guinea streams. Arch. Hydrobiol, 119: 35-53.

DUDGEON, D., 1996, Life histories, secondary production, and microdistribution of heptageniid mayflies (Ephemeroptera) in a tropical forest stream. J. Zool., 240: 341-361.

DUDGEON, D., 1997, Life histories, secondary production, and microdistribution of hydropsychid caddisflies (Trichoptera) in a tropical forest stream. J. Zool., 243: 191-210.

FLECKER, A. S. \& FEIFAREK. B., 1994, Disturbance and temporal variability of invertebrate assemblages in two Andean streams. Freshw. Biol., 31: 131-142.

FROEHLICH, C. G., 1984, Brazilian Plecoptera 4. Nymphs of perlid genera from southeastern Brazil. Ann. Limnol., 20(1-2): 43-48.

FROEHLICH, C. G. \& OLIVEIRA, L. G., 1997, Ephemeroptera and Plecoptera nymphs from riffles in low-order streams 
in Southeastern Brazil, pp. 180-185. In: P. Landolt \& M. Sartori (eds.), Ephemeroptera \& Plecoptera: BiologyEcology-Systematics. MTL, Fribourg, XI + 596p.

GILLER, P.S. \& MALMQVIST, B., 1998, The Biology of streams and rivers: Biology of Habitat. Oxford University Press, Oxford, VIII + 296p.

HILDREW, A. G. \& TOWNSEND, C. R., 1987, Organization in Freshwater Benthic Communities, pp. 347-371. In: Gee, J. H. R. \& Giller P. S. (eds.), Organization of Communities: Past and Present. Blackwell Scientific Publications, Oxford, 576p.

HYNES, H. B. N., 1970, The Ecology of Running Waters. Liverpool University Press, Liverpool, XXIV + 555p.

ILLIES, J., 1964, The invertebrate fauna of the Huallaga, a Peruvian tributary of the Amazon river, from the sources down to Tingo Maria. Verh. Internat. Ver. Limnol., 15: 1077-1083.

JACOBSEN, D. \& ENCALADA, A., 1998, The macroinvertebrate fauna of Ecuadorian high-land streams in wet and dry season. Arch. Hydrobiol., 142(1): 53-70.

LIND, O. T., 1979, Handbook of Common Methods in Limnology. The C. V. Mosby Company, London, XI + 199p.

MACAN, T. T., 1962, Ecology of aquatic insects. Annu. Rev. Entomol., 7: 261-288.

MARCHANT, R; BARMUTA, L. A. \& CHESSMAN, B. C., 1995, Influence of sample quantification and taxonomic resolution on the ordination of macroinvertebrate comunities from running waters in Victoria, Australia. Mar. Freshw. Res., 46: 501-506.

MCCABE, D. J. \& GOTELLI, N. G., 2000, Effects of disturbance frequency, intensity, and area on assemblages of stream macroinvertebrates. Oecologia, 124: 270-279.

MCCUNE, B. \& MEFFORD, M. J., 1995, PC-ORD. Multivariate Analysis of Ecological Data. Version 2.0, MjM Software Design. Gleneden Beach, Oregon, USA.

MELO, A. S. \& FROEHLICH, C. G., 2001, Macroinvertebrates in neotropical streams: richness patterns along a catchment and assemblage structure between 2 seasons. J. N. Am. Benth. Soc., 20(1): 1-16.

NIMER, E., 1989, Climatologia do Brasil. IBGE, Rio de Janeiro, 421p.

OLIVEIRA, L. G., BISPO, P. C. \& SÁ, N. C., 1997, Ecologia de comunidades de insetos bentônicos (Ephemeroptera, Plecoptera e Trichoptera), em córregos de cerrado do Parque Ecológico de Goiânia-GO, Brasil. Revta Bras. Zool., 14: 867-876.

OLIVEIRA, L. G. \& FROEHLICH, C. G., 1997, The Trichoptera (Insecta) faunda of a "cerrado" stream in Southeastern Brazil. Naturalia, 22: 183-127

PETERSEN, R. H. \& VAN EECKHAUTE, L., 1992, Distributions of Ephemeroptera, Plecoptera, and Trichoptera of three maritime catchments differing in pH. Freshw. Biol., 27: 65-78.
RICHARDS, C., HOST, G. E. \& ARTHUR, J. W., 1993, Identification of predominant environmental factors struturing stream macroinvertebrate communities within a large agricultural catchment. Freshw. Biol., 29: 285-294.

ROSENBERG, D. M. \& RESH, V. H., 1993, Freshwater Biomonitoring and Benthic Macroinvertebrates. Chapman \& Hall, London, IX + 488p.

ROSSER, Z. C. \& PEARSON, R. G., 1995, Responses of rock to physical disturbance in two Australian tropical rainforest streams. J. N. Am. Benth. Soc., 14(1): 183-196.

SCARSBROOK, M. R. \& TOWNSEND, C. R., 1993, stream community structure in relation to spatial and temporal variation: a habitat templet study of two contrasting New Zealand streams. Freshw. Biol., 29: 395-410.

STATZNER, B. \& BORCHARDT, D., 1994, Longitudinal Patterns and Process Along streams: Modelling Ecological Responses to Physical Gradients, pp. 113-140. In: Giller, P. S.; A. G. Hildrew \&. D. G. Raffaelli (eds.). Aquatic Ecology: Scale, Pattern and Process. British Ecological Society and Blackwell Science, Oxford, XIII +649p.

STRAHLER, H. N, 1957, Quantitative analysis of watershed geomorphology. Am. Geoph. Unio Trans., 33: 913-920.

TER BRAAK, C. J. F., 1986, Canonical Correspondence Analysis: a new eigenvector technique for multivariate direct gradients analysis. Ecology, 67: 1167-1179.

TOWNSED, C. R., DOLÉDEC, S. \& SCARSBROOK, M., 1997, Species traits in relation to temporal and spatial heterogeneity in streams: a test of habitat templet theory. Freshw. Biol., 37: 367-387.

USSEGLIO-POLATERA, P. \& TACHET, H., 1994, Theorical habitat templets, species traits, and species richness: Plecoptera and Ephemeropetra in Upper Rhône river and its floodplain. Freshw. Biol., 31: 357-375.

VANNOTE, R. L., MINSHALL, G. W., CUMMINS, K. W. L., SEDELL, J. R. \& CUSHING, C. E., 1980, The river Continuum Concept. Can. J. Fish. Aquat. Sci., 37: 130-137.

WIGGINS, G. B., 1996, Larvae of the North America Caddisfy Genera (Trichoptera). University of Toronto Press, Toronto, $\mathrm{XI}+457 \mathrm{p}$.

YULE, C. M., 1995, Benthic invertebrate fauna of an aseasonal tropical mountain stream on Bougainville Island, Papua New Guinea. Mar. Fresw. Res., 46: 507-518.

ZAMORA-MUÑOZ，C. \& ALBA-TERCEDOR, J., 1996, Bioassessment of organically polluted Spanish rivers, using a biotic index and multivariate methods. J. N. Am. Benth. Soc., 15: 332-352.

ZAMORA-MUÑOZ, C., SANCHEZ-ORTEGA, A. \& ALBA-TERCEDOR, J., 1993, Physico-chemical factors that determine the distribution of mayflies and stoneflies in a high-mountain stream in southern Europe (Sierra Nevada, Southern Spain). Aquatic Insects, 15: 11-20. 